\title{
Flos campi et lilium convallium. Third interpretation of the lily in the iconography of The Annunciation in Italian Trecento art from patristic and theological sources
}

\section{Flos campi et lilium convallium. Tercera interpretación del lirio en la iconografía de La Anunciación en el Trecento italiano a la luz de fuentes patrísticas y teológicas}

\author{
José María SALVAdOR GONZÁLEZ \\ Universidad Complutense de Madrid \\ Departamento de Historia del Arte I (Medieval) \\ jmsalvad@ucm.es
}

Recibido: $15 / 03 / 2014$

Aprobado: 21/04/2014

\begin{abstract}
This paper (which complements two previous works of our authorship) proposes to interpret the bouquet of lilies in medieval images of The Annunciation in two essentially intertwined dogmatic meanings, related to Christology and Mariology. Contradicting conventional "explanations" of such flower in this Marian scene, we found our proposal in many and consistent testimony of some prestigious Church Fathers and medieval theologians, glossing the biblical sentence Ego sum flos campi et lilium convallium. Such lyrical expression is seen by those authors as a clear metaphor that identifies Christ, the incarnate Son of God, and that, as such, also refers to Mary, in whose virginal womb the Son of God's incarnation is produced. Thus, based on the solid patristic and theological tradition on this biblical sentence, we dare to interpret the bouquet of lilies in paintings of the Annunciation (illustrated here by nine paintings of the Italian Trecento) as a double metaphor, which means both the supernatural human incarnation of God the Son and the virginal divine motherhood of Mary.
\end{abstract}

Key Words: Medieval art, iconography, The Annunciation, Mariology, Christology, Patrology, Italian Trecento painting.

Resumen: El presente artículo (que complementa otros dos trabajos previos de nuestra autoría) propone interpretar el ramo de lirios en las imágenes medievales de La Anunciación según dos significados dogmáticos, cristológico y mariológico, esencialmente interrelacionados. Contradiciendo las "explicaciones" convencionales de dicha flor en esa escena mariana, fundamos nuestra propuesta en múltiples y concordantes testimonios de prestigiosos Padres de la Iglesia y teólogos medievales, al glosar la bíblica frase Ego sum flos campi et lilium convallium. Tan lírica expresión es vista por esos autores como una clara metáfora que identifica a Cristo, Hijo de Dios encarnado, y que, por tal motivo, alude de rebote también a María, en cuyo seno virginal se verifica la encarnación de Dios Hijo. Así, basándonos en la sólida tradición patrística y teológica sobre la referida frase bíblica, nos atrevemos a interpretar el ramo de lirios en las imágenes de La Anunciación -ilustradas aquí por nueve pinturas del Trecento italiano - como una doble metáfora, que significa al mismo tiempo la sobrenatural encarnación humana de Dios Hijo y la virginal maternidad divina de María.

Palabras clave: Arte medieval, iconografía, La Anunciación, mariología, cristología, patrística, pintura italiana del Trecento.

Summary: 1. Introduction. 2. The stem of lilies in the iconography of the Annunciation in Italian Trecento painting. 3. The biblical expression flos campi et lilium convallium, a metaphor for the incarnation of God the Son in the Virgin Mary's womb. 4. Conclusions. Sources and bibliography. 


\section{Introduction}

The symbolic motif of the stem of lilies in the late medieval images of The Annunciation has allowed us to make already two iconographic approaches based on patristic and theological texts: the first refers to the Isaiah's prophecy on the flower sprung at the Jesse's root: ${ }^{1}$ the second approach focuses on the miraculous flourishing of the Aaron's dry rod. ${ }^{2}$ We undertake now a third interpretation of the same iconographic metaphor from the exegesis proposed by some Church Fathers and medieval theologians in allusion to "the flower of the field, and the lily of the valleys" from the Song of Songs. However, as our first two articles constitute the background fabric that provides a glimpse into the process that we will continue in this third paper, it is useful to summarize the essence of the conclusions of these two previous studies. Here are the most relevant:

The early and original iconography of The Annunciation, based exclusively on the Gospel of Luke, without interference from the apocryphal texts nor from The Golden Legend, ${ }^{3}$ increased significantly since the eleventh century, and especially during the Late Middle Ages, its formal and conceptual complexity, through subtle symbols and metaphors, under the stimulus of the progressive devotion to the Virgin and the doctrinal refinement of the Mariology.

We conclude also that the manifest prominence accorded to the stem of lilies carried by the archangel or placed in a vase in almost all the late medieval Annunciations is not explained fully if it is interpreted in the generic sense of purity and virginity in general -not even applying it to the Virgin Mary-, as do often the experts in symbolism and iconography.

We have proposed, on the other hand, the hypothesis that the outstanding exhibition of the stem of lilies in the late medieval Annunciations is explained by the fact that the iconographic programmers of such images are inspired by a long and consistent patristic and theological tradition, according to which many ecclesiastical authors in the Middle Ages interpret the flower sprung from a stem as a simultaneously Mariological and Christological symbolism, identifying Jesus with the flower and Mary with the stem.

In fact, the most valuable contribution of our first two articles was to explain and analyze the exegesis of countless Church Fathers, Doctors and medieval theologians that interpret the flowering of the outbreak at the Jesse's root

\footnotetext{
${ }^{1}$ José María SALVADOR GonzÁlez, "Flos de radice Iesse. A hermeneutic approach to the theme of the lily in the Spanish Gothic painting of The Annunciation from patristic and theological sources", Eikón Imago, 4, July-December 2013, Madrid, Universidad Complutense de Madrid, p. 183-222.

2 José María SALVAdor GonZÁLEZ, "In virga Aaron Maria ostendebatur. Nueva interpretación del ramo de lirios en La Anunciación gótica española a la luz de fuentes patrísticas y teológicas", Anales de Historia de Arte, n 24, Universidad Complutense de Madrid, 2014, p. $37-60$

${ }^{3}$ Santiago de la VorÁGine, La Leyenda Dorada (Traducción del latín: Fray José Manuel Macías), Madrid, Alianza Editorial, Col. Alianza Forma, 29-30, 1990, 2 vols.
} 
(according to the Isaiah's prophecy) and the flowering of the Aaron's dry rod as two analogous prefigurations of the incarnation of God the Son (the flower) in the virginal womb of Mary (the stem or rod).

Synthesized thus the essential findings of our first two iconographic interpretations of the stem of lilies in the late medieval Annunciations, we undertake now -looking at nine representations of this item in Italian Trecento painting - a third hermeneutic approach of this floral element from the biblical reference to "the flower of the field, and the lily of the valleys".

\section{The stem of lilies in the iconography of the Annunciation in Italian Trecento painting}

In Italian Trecento painting, as well as in other regional productions of late medieval European art, the images of The Annunciation to Mary include very often a stem of lilies, carried by the archangel or put in a vase or a jug next to the Virgin. This reiterative iconographic detail will reveal, in the second part of the current paper, a deep and meaningful dogmatic core, as many Church Fathers and medieval theologians elucidate with their respective exegesis. Before that, we will look at nine Italian Trecento paintings that illustrate with sharpness that peculiar iconographic detail.

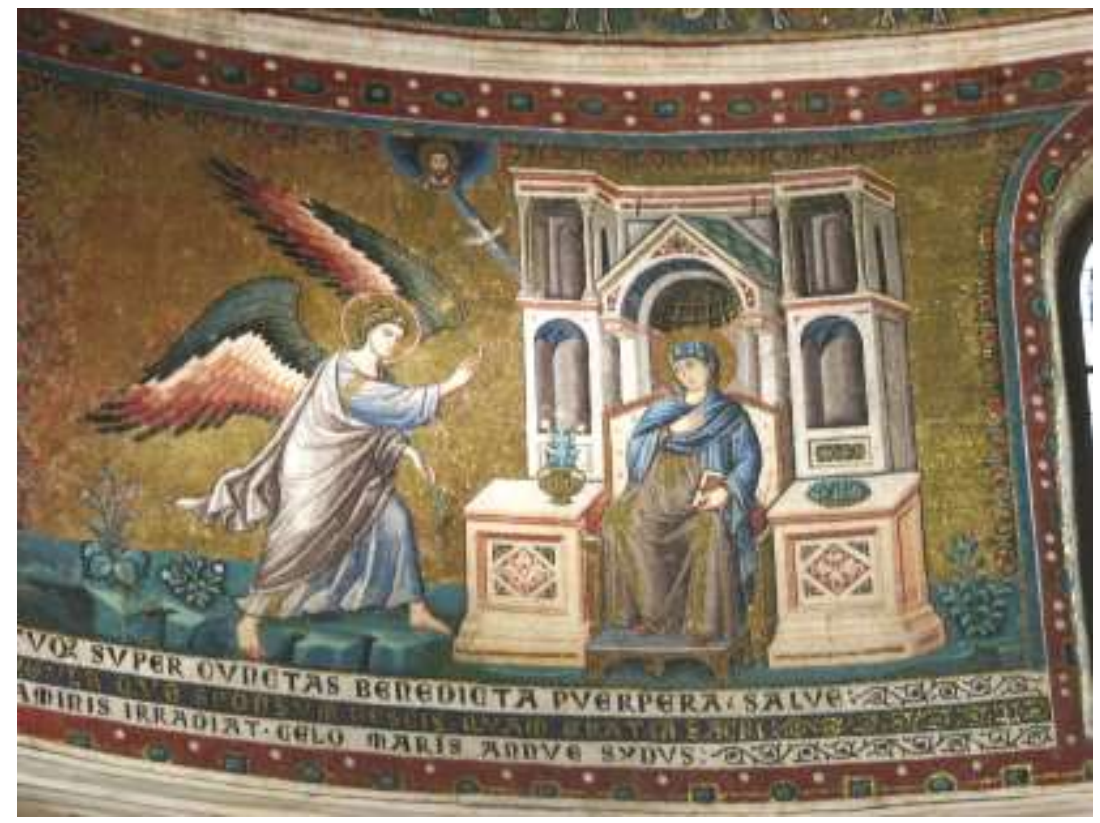

Fig. 1. Pietro Cavallini, The Annunciation, c. 1296-1300, Basilica di Santa Maria in Trastevere, Rome. Image from Wikimedia Commons (Last access: 11/02/2014)

Pietro Cavallini (c. 1250-C. 1330), in his Annunciation, c. 1296-1300, made in mosaic -at the request of the cardinal Bertoldo Stefaneschi- in the apse of the basilica of Santa Maria in Trastevere in Rome (Fig 1), represents the Virgin sitting on a monumental throne of architectural aspect, with a vaulted canopy and an apse-like seatback, in clear reference to a form of a temple. Such circumstance seem to suggest the perfect identification Mary=Church, an allegorical identification sustained by many ecclesiastical authors during the Middle Ages. 
Carrying a closed book in her left hand and with her right arm on her chest, the Virgin tilts slightly backwards in a gesture of fear and hesitation. Walking with great strides on the outer space and deploying his colorful wings, the archangel Gabriel bears in his left hand a cane (a rod? a stem of lilies?), while with his right hand points to the Virgin in a gesture of blessing, displaying his congratulating salutation: Benedicta tu in mulieribus. ${ }^{4}$ Between the two characters, resting on a shelf of the architectonic structure, you can see in a prominent highlight a wide vase with three branches of lily, each with a flower expanded in its cusp. At the top of the scene, with the aspect of a bust glowing in the middle of a round, blue mandorla or halo, God the Father looks upon the Virgin, while sending toward her the ray of life, on whose refulgent trail the fertilizing Holy Spirit flies in the form of a dove. One of the inscriptions in the epigraphic band under the scene complements the bias of the Mary's glorification in this scene, in proclaiming: Super cunctas benedicta puerpera salve.

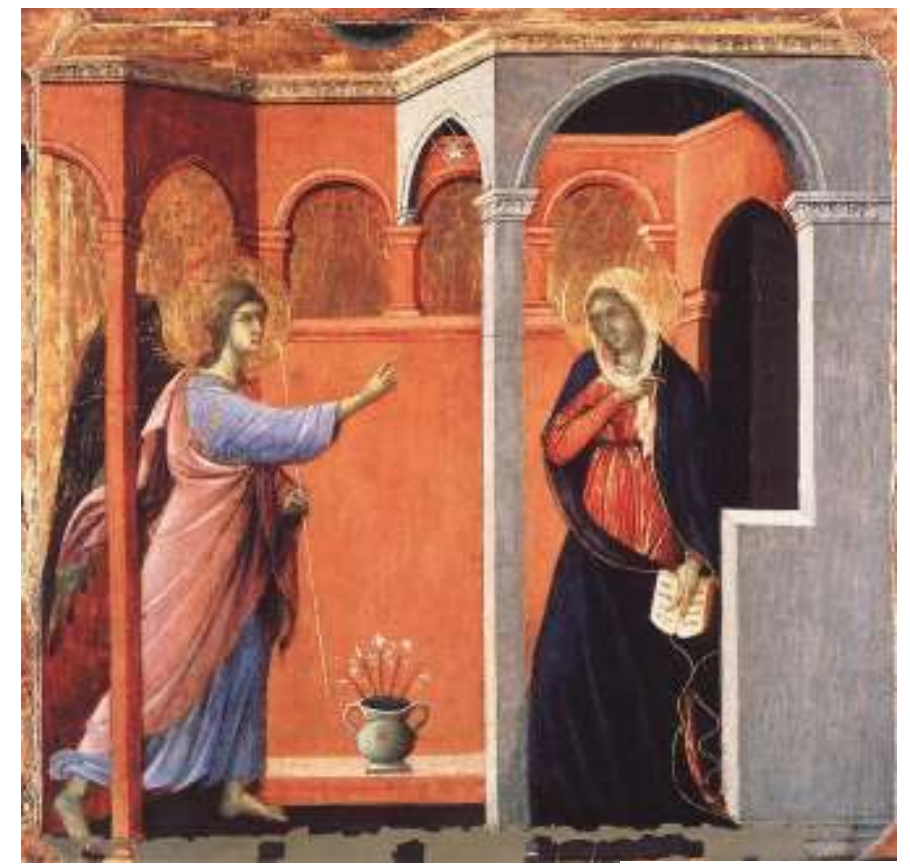

Fig. 2. Duccio, The Annunciation, 1308-1311, National Gallery, London. Image from Web Gallery of Art (Last access: 11/02/2014)

Duccio di Buoninsegna, in his Annunciation, 1308-1311, formerly panel of the front predella of the famous Maestà in the Siena Cathedral, now in the National Gallery of London (Fig 2), ${ }^{6}$ takes a compositional structure clearly inspired by

\footnotetext{
${ }^{4}$ Lk 1, 28. In Biblia Sacra iuxta Vulgatam Clementinam. Nova editio (Logicis partitionibus aliisque subsidiis ornata a Alberto Colunga et Laurentio Turrado), Madrid, La Editorial Católica, Biblioteca de Autores Cristianos, 12 edición, 2005, p. 1011.

5 "Hail above all women, given birth blessed".

${ }^{6}$ Duccio de Buoninsegna, The Annunciation, 1308-1311, tempera and gold on wood, 43 x 44 $\mathrm{cm}$, originally panel of the front predella of La Maestà in Siena Cathedral, now in the National Gallery of Art, London.
} 
Byzantine models, which will be quite common for this iconographic matter in the art of Western Europe: bringing in his left hand a long stick or crosier with fleuron, the archangel walks with great strides franking the entrance gate into the Mary's room, while blessing her with his right hand. Surprised standing with her book open, the Virgin retracts herself with timid modesty, throwing her body backwards on her left leg, lowering her head and covering her chest with her right arm. At the top of the panel the Most High allows barely discern his presence in the brief span of a blue circle, from which he emits, with the predictable divine Spirit in the form of a dove, the impregnating ray, which penetrates through the Mary's ear to signify her conceptio per aurem. ${ }^{7}$ In the foreground on the floor, serving as a fulcrum and link between the two partners, and as pendant-almost just in the axis - of the godhead suggested in the halo, the inevitable vase with lilies becomes the clear evidence of the profound theological meanings that we will explain later.

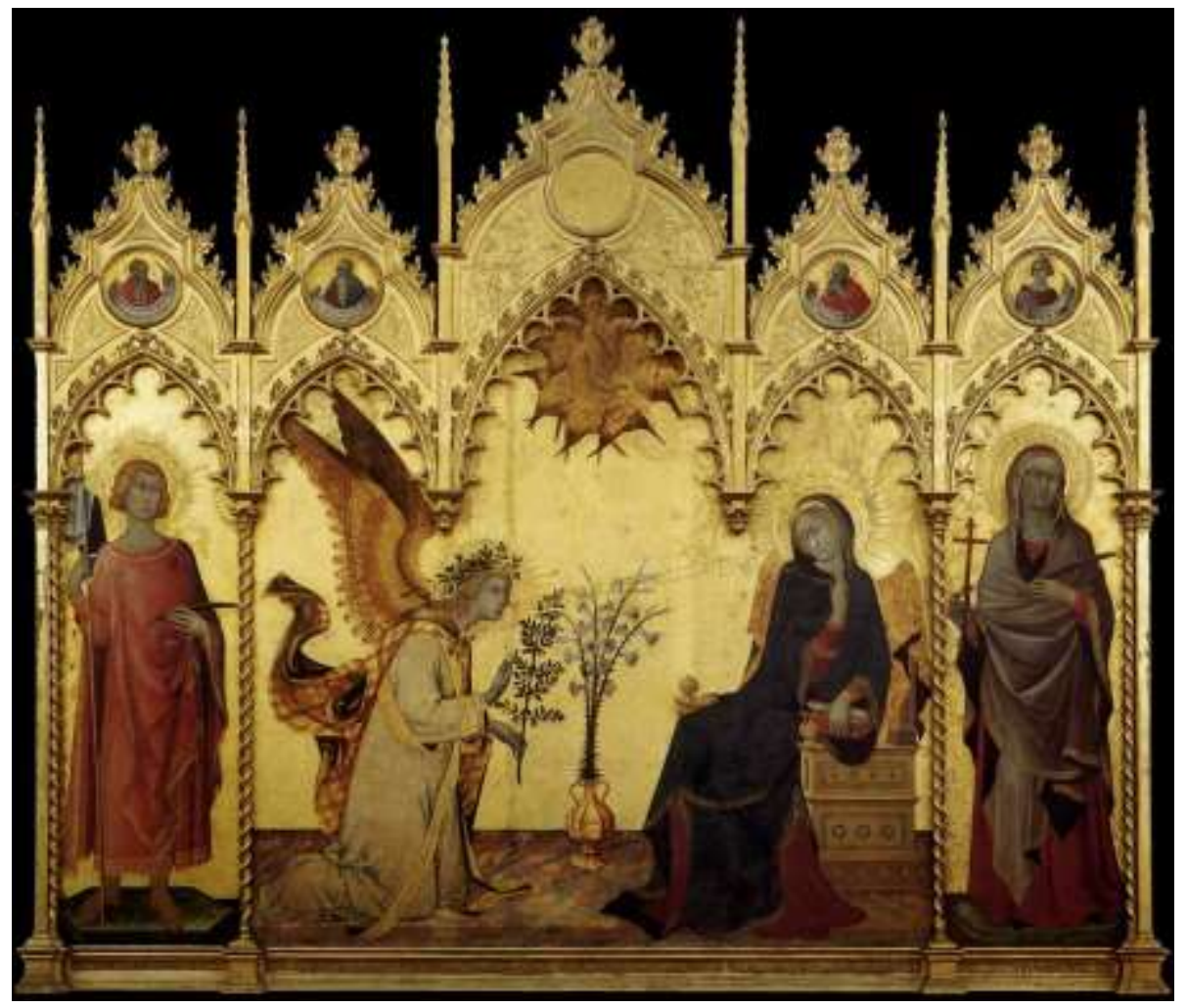

Fig. 3. Simone Martini (with Lippo Memmi), L'Annunciazione con $i$ Santi Ansano e Margherita, 1333. Galleria degli Uffizi, Florence. Image from Wikimedia Commons (Last access: $11 / 02 / 2014)$

Simone Martini introduces some significant variants in L'Annunciazione con $i$ Santi Ansano e Margherita, 1333 (Fig. 3), an altarpiece painted in collaboration with his disciple and brother in law Lippo $\mathrm{Memmi}^{8}$ for the chapel

\footnotetext{
${ }^{7}$ On the theme of the conceptio per aurem, we intend soon to write an analytical article.

${ }^{8}$ The figures of Sant'Ansano (patron of Siena) and Santa Margherita, on the side panels of the altarpiece, are attributed to Lippo Memmi.
} 
of Sant'Ansano in the Siena Cathedral, now in the Galleria degli Uffizi in Florence. ${ }^{9}$ On the abstract background of gold leaf, which omits any scenographic detail (except for the throne of Mary), the first variant is in the angel's position: with his head girded with a garland of olive tree, he prostrates before the enthroned Virgin and recognizes her as his Lady and Queen, and gives her a olive branch (symbol of coming peacefully) with his left hand; furthermore he points upwards with his right index finger to express the Almighty's message, while assuring her that she will be covered with the fertilizing shade of the Almighty (Virtus Altissimi obumbrabit tibi). ${ }^{10}$ The heavenly announcement is evident also in the golden epigraphic inscription Ave, gratia plena Dominus tecum, which, out of the Gabriel's mouth, reaches the Mary's ear, in a new and imaginative way to visualize the metaphorical conceptio per aurem.

The second innovative detail introduced by Duccio lies in the fact that despite her gesture of retracting herself due to fear and modesty while holding open the prayer book in her left hand, the Virgin appears enthroned with majestic dignity, to signify her investiture as Queen of heaven as a result of her newly verified divine maternity.

The third relevant change adopted by Duccio derives from the fact that, in the absence of the usual impregnating light ray, the godhead is presented here with the mere figure of the Holy Spirit's dove, framed by a swanky red round mandorla of cherubim. Moreover, placed on the floor in the very center of the composition, in perfect axis with the divine Spirit, a great vase filled with upright stems of lilies functions as an eloquent metaphor of the dogmatic content of the dialog between both partners.

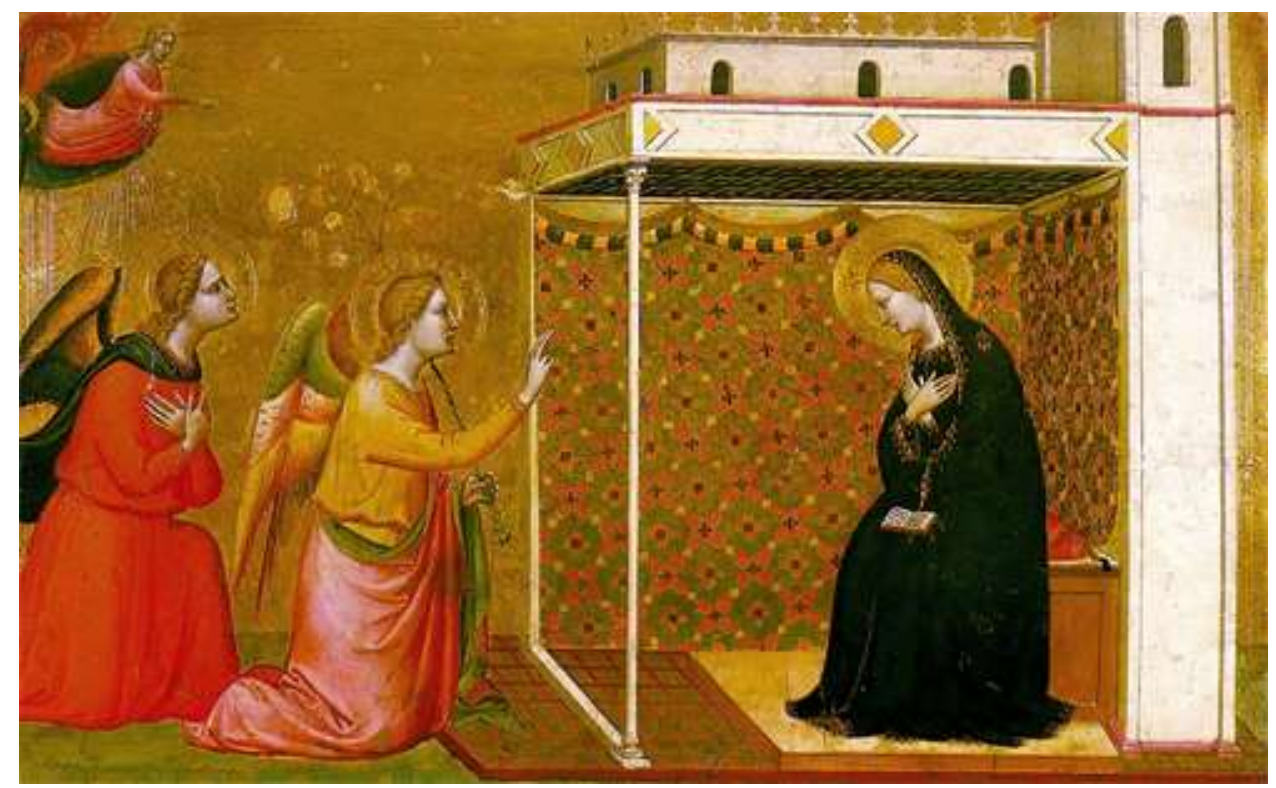

Fig. 4. Bernardo Daddi, The Annunciation, c. 1335. Musée du Louvre, Paris. Image from Web Gallery of Art. (Last access: 11/02/2014)

\footnotetext{
${ }^{9}$ Simone Martini (with Lippo Memmi), L'Annunciazione con i Santi Ansano e Margherita, 1333 , tempera and gold on wood, $184 \times 210 \mathrm{~cm}$. Galleria degli Uffizi, Florence.

${ }^{10}$ Lk 1, 35. In Biblia Sacra iuxta Vulgatam ..., op. cit., p. 1011.
} 
Bernardo Daddi (c. 1280-1348), in his Annunciation, c, 1335, of the Musée du Louvre (Fig 4), ${ }^{11}$ adds the option of introducing a second angel accompanying Gabriel. Carrying in his left hand a huge stem of lilies, the latter designates/blesses the seated Virgin, who, absorbed with fervor in the privacy of her simple alcove, receives downcast and humble the heavenly message, with her hands crossed on her chest and the prayer book open on her lap. From the top left corner, God the Father, whole body in a halo of splendor, points with his index finger to the Virgin - to signify her election as the Mother of God-, sending out toward her head the divine life's ray, by whose trail the dove of the fertilizing Holy Spirit flutters.

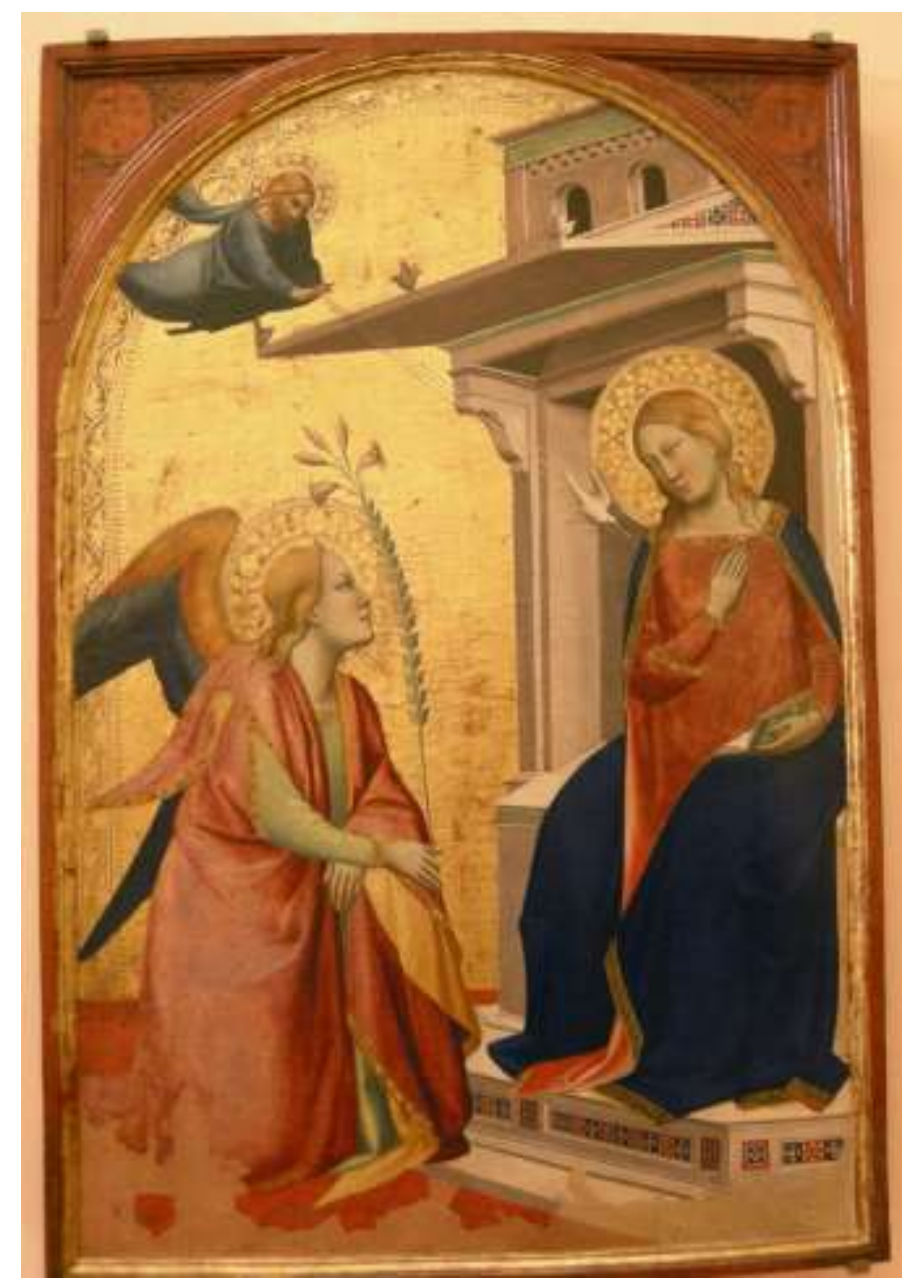

Fig. 5. Taddeo Gaddi, The Annunciation, 1340-45. Museo Bandini, Fiesole. Image from Wikimedia Commons (Las access: 11/02/2014)

In his Annunciation, 1340-1345, of the Bandini Museum (Fig 5), ${ }^{12}$ Taddeo Gaddi proposes a compositional structure substantially similar to that of the preceding panel, with only two notable exceptions: in addition to resume here the

\footnotetext{
${ }^{11}$ Bernardo Daddi, The Annunciation, c, 1335, tempera and gold on wood, 43 x $70 \mathrm{~cm}$. Musée du Louvre, Paris.

12 Taddeo Gaddi, The Annunciation, 1340-45, tempera and gold on wood. Museo Bandini, Fiesole.
} 
usual resource of depicting the Archangel Gabriel as the only celestial messenger, the artist figures the Virgin's seat as a monumental architectural throne -a true synthesis of house/church-, in a way quite similar to the one raised by Pietro Cavallini in the Roman mosaic of Santa Maria in Trastevere newly described. Moreover, Taddeo Gaddi introduces almost the same ingredients as Bernardo Daddi: the Archangel Gabriel, with his huge stem of lilies, kneeling down as a sign of allegiance to his enthroned Madam, while, downcast and with the book open, she sees flying toward her abdomen to Holy Spirit, sent through the life-giving ray by God the Father, who levitates over the scene.

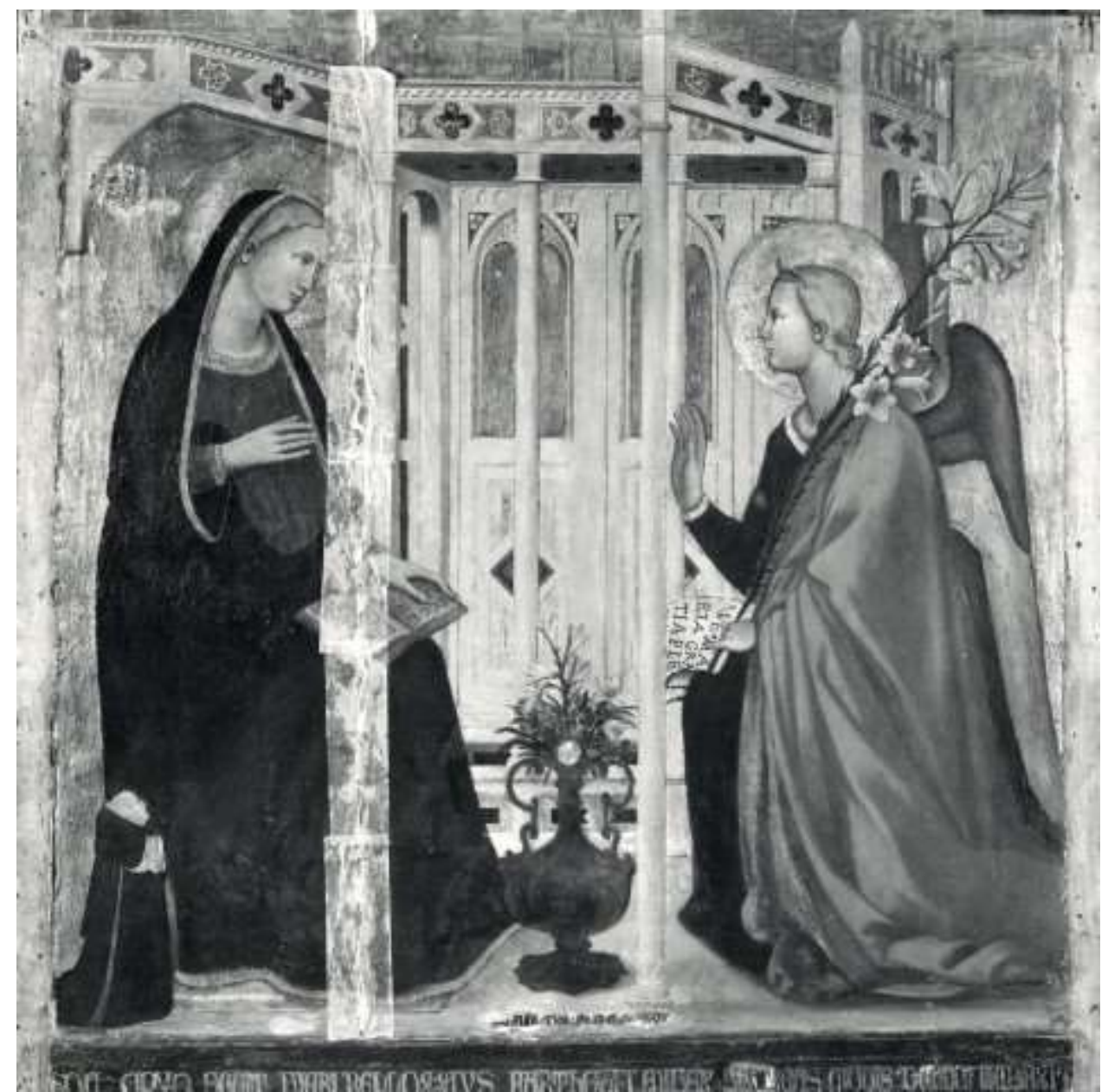

Fig. 6. Andrea Orcagna, The Annunciation, 1346. Count Gerli Collection, Milan Image from Wikimedia Commons. (Last access: 11/02/2014)

Flaunting an undeniable compositional audacity, Andrea Orcagna, in The Annunciation, 1346, in the Count Gerli Collection (Fig 6), ${ }^{13}$ completely reverses the traditional position of the two protagonists: he places thus on the left the Virgin -next to whom the tiny ecclesiastical donor appears kneeling -, while to the right the archangel prostrates himself on his knees. Gabriel takes a couple of huge stems of lilies with the same left hand with which displays a wide scroll on

${ }^{13}$ Andrea Orcagna, The Annunciation, 1346, tempera on wood. Count Gerli Collection, Milan. 
which is inscribed the congratulatory salutation Ave Maria gratia ple[na]. ${ }^{14}$ The demure maiden is likely to reply, in visual dialog, to the angelic greeting through the final sentence written in the book that she keeps open on her knees, an acceptance phrase of which only its initial word is readable: Ecce. ${ }^{15}$ As expected, a vase with stems of lilies, focused in the foreground on the floor, accentuates with obvious redundancy the doctrinal meaning content in the stem that Gabriel flies over his shoulder.

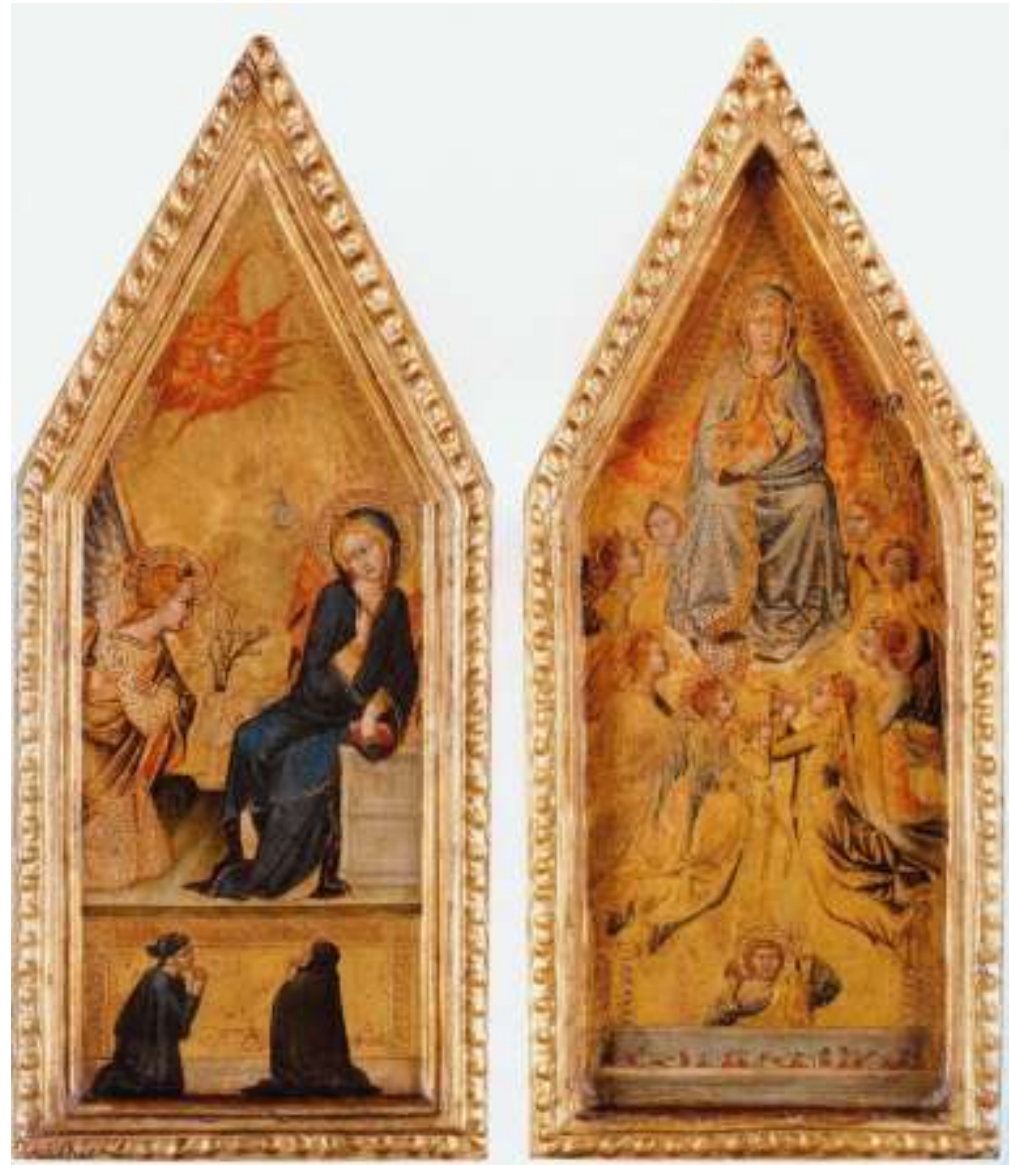

Fig. 7. Francesco di Vannuccio, Dittico con Annunciazione e due devoti, Assunzione, c.1380. Girton College. Image from Wikimedia Commons (Last access: 11/02/2014)

Francesco di Vannuccio (active in Siena in 1356-1389), when interpreting this thematic issue in the left pane of his Dittico con Annunciazione e due devote. Assunzione, c.1380, at the Girton College in Cambridge, England (Fig 7), ${ }^{16}$ was

\footnotetext{
14 “Ave, gratia plena: Dominus tecum: benedicta tu in mulieribus." (Lk 1, 28. In Biblia sacra juxta Vulgatam..., p. 1011).

${ }^{15}$ The vertical band of the restoration superimposed on the painting in the only picture we know of this work does not allow us to read the text written on the book of Mary. Maybe it's all whole or, more likely, the first part of the final response that Mary gives the divine proposal transmitted by the angel: Ecce ancilla Domini [fiat mihi secundum verbum tuum]. (Lk 1, 38. In Biblia sacra juxta Vulgatam..., p. 1011).

${ }^{16}$ Francesco di Vannuccio, Dittico con Annunciazione e due devoti. Assunzione, c.1380, tempera and gold on wood. Girton College, Cambridge, England.
} 
inspired plainly in the prestigious altarpiece by Simone Martini discussed earlier. In fact, in the panel of Vannuccio the figure of the Virgin on her throne is almost a literal copy of that of the Martini's altarpiece. Vannuccio also takes from the Sienese master two other analogous resources: first and foremost, framed in a round mandorla of cherubim, the presence of God the Father (here suggested by his hand in a gesture of blessing), a focus which emits the life-giving beam on which flies the dove of the divine Spirit; secondly, the total absence of scenic elements, before the imperative splendor of the neutral background of gold leaf on front of which the two partners' figures stand out. On the contrary, Vannuccio introduces a couple of minor changes to the Simone Martini's model: in addition to include two tiny donors kneeling at the base of the scene, the angel does not carry olive branches in his head or in his hand, and crosses, in contrast, his arms over his chest. Moreover, the stems of lily emerging from the vase express their doctrinal symbolism as the indissoluble link between the two protagonists, thus filling the hiatus between both.

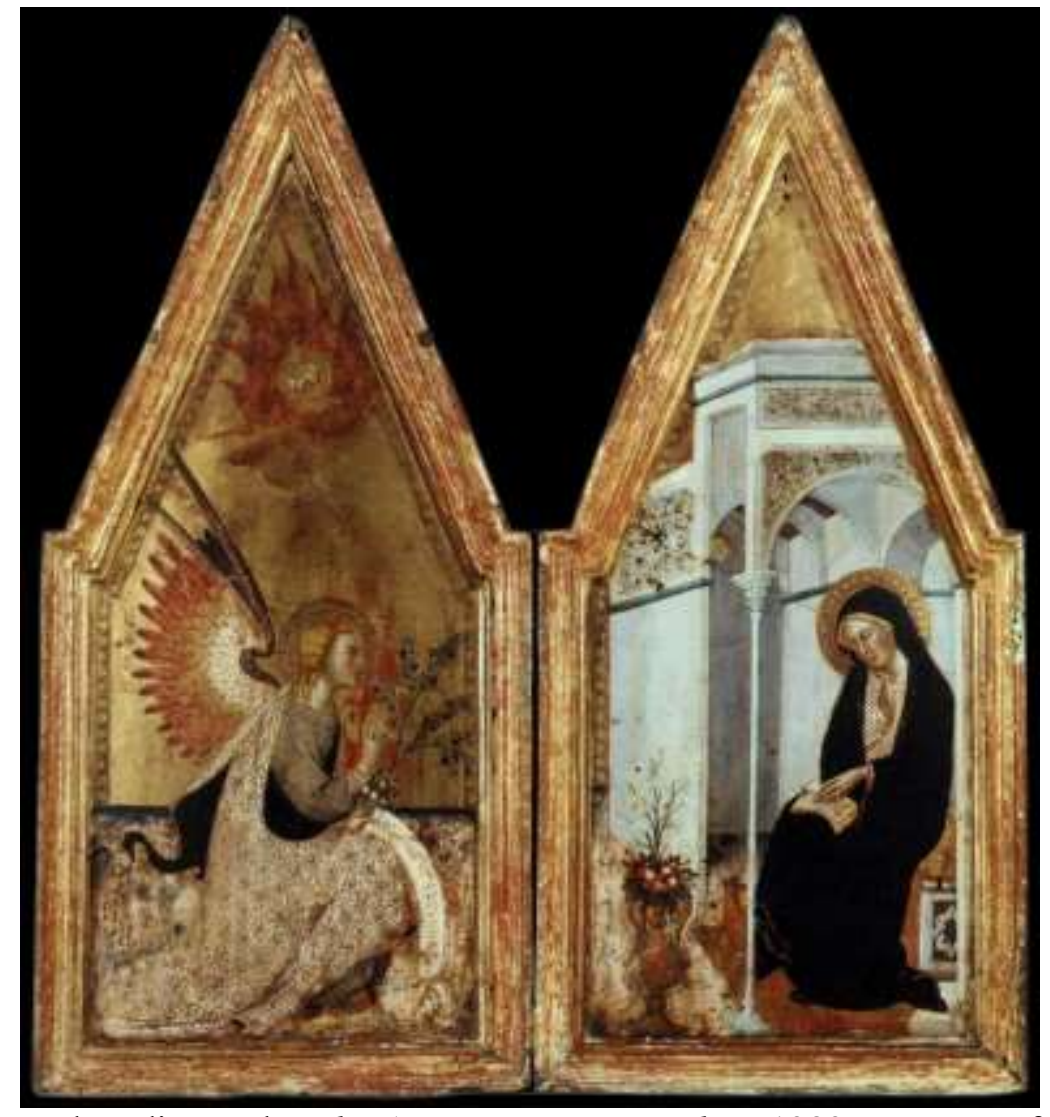

Fig. 8. Andrea di Bartolo, The Annunciation Diptych, c. 1383. Museum of Fine Arts, Budapest. Image from Wikimedia Commons (Last access: 11/02/2014)

Also Andrea di Bartolo (c. 1360/70-1428, in his Annunciation Diptych, c. 1383, in the Museum of Fine Arts, Budapest (Fig 8), ${ }^{17}$ picks up two components of the Simone Martini's model: the olive branch carried by the angel in his left

\footnotetext{
${ }^{17}$ Andrea di Bartolo, The Annunciation Diptych, c. 1383, tempera and gold on wood. Museum of Fine Arts, Budapest.
} 
hand -with which deploys in addition a long phylactery with inscriptions-, and the presence of godhead in the middle of the red round mandorla of cherubim. Di Bartolo introduces a significant variant in his panel, by identifying the godhead not with God the Father, but with God the Son, represented here as a child face, to better suggest his incarnation in the Mary's womb, after she was impregnated by the Holy Spirit, in flight toward her in the trail of the divine ray. Otherwise, Andrea di Bartolo poses in this diptych a sharp contrast between the abstract gold background of the left pane with the concrete architectural scenography that hosts Mary in the right pane: the floor -where the Virgin's home and throne, the kneeling archangel and the vase with the unavoidable stems of lilies are placed solidly - is the only element that establishes the necessary visual and narrative link between these two contrasting panels.

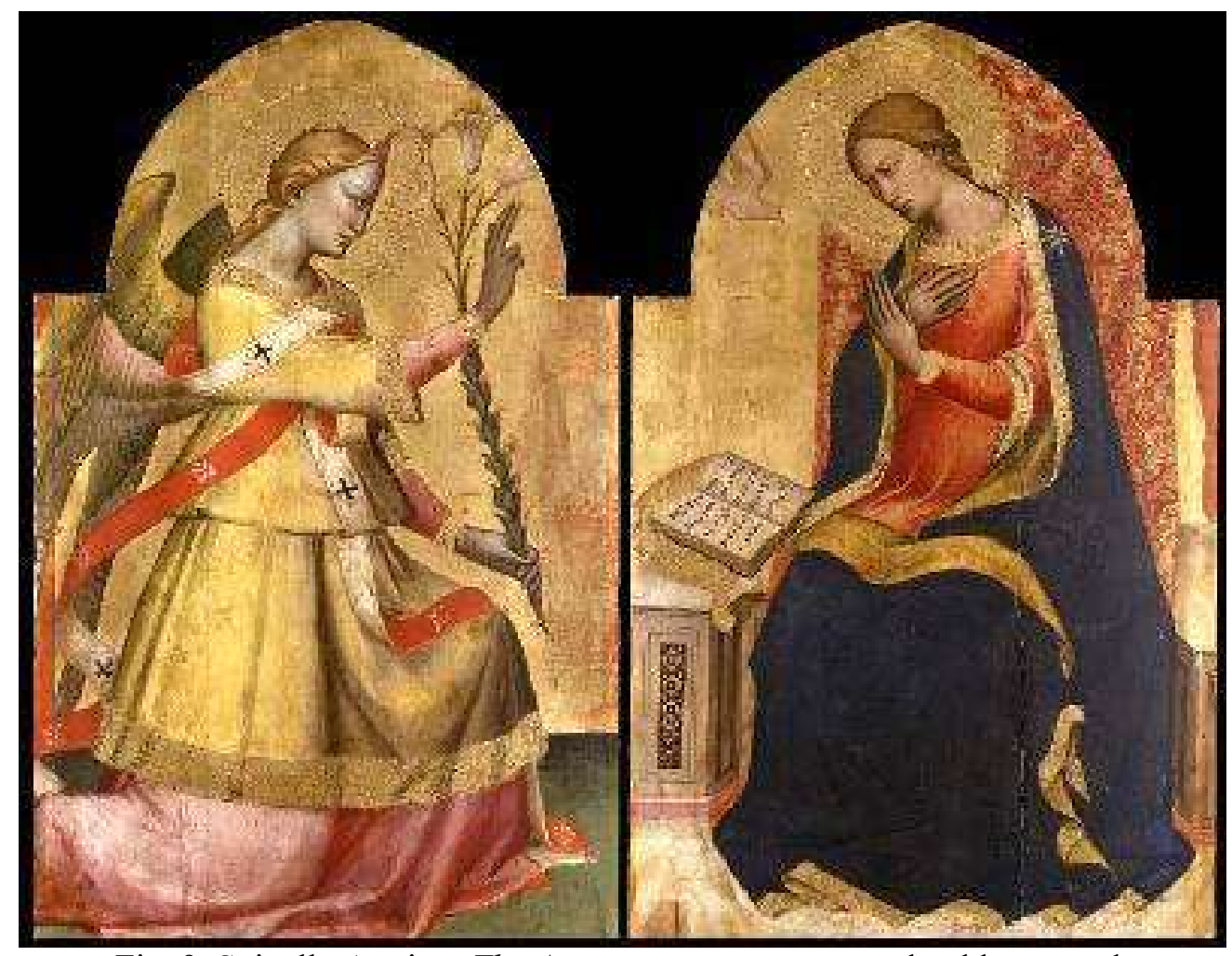

Fig. 9. Spinello Aretino, The Annunciation, tempera and gold on wood. Image from Wikimedia Commons (Last access: 11/02/2014)

Spinello Aretino (1345-1410) does not bring any significant development in his Annunciation (Fig 9). ${ }^{18}$ The gestures and situations of both characters adopt the typical conventions of the theme: the archangel kneels pointing toward the heaven, the Virgin is seated on a throne, with her hands crossed with modesty on her chest, with the prayer book open, while the dove of the divine Spirit flies toward her. As a less frequent variant, Spinello places here the stem of lilies in the hands of Gabriel, instead of depositing it in the usual vase or jar.

${ }^{18}$ Spinello Aretino, The Annunciation, tempera and gold on wood (without additional data). Image from Wikimedia Commons (Last access: 19/03/2014). 


\section{The biblical expression flos campi et lilium convallium, a metaphor for the incarnation of God the Son in the Virgin Mary's womb}

As we said before, the patent prominence that the stem of lilies acquires in almost all late medieval images of The Annunciation, as the nine Italian paintings analyzed here have illustrated, is due to strict dogmatic reasons, which are elucidated clearly in many consistent exegesis of numerous Church Fathers and medieval theologians, who interpret the flower as Christ, God the Son incarnate in the Mary's womb, and the stem or stalk as Mary, virginal Mother of God the Son incarnate.

In our first two articles ${ }^{19}$ we have shown already the patristic and theological tradition that, in interpreting the flowering of the stem in the root of Jesse and that of the Aaron's dry rod, sees in this stem of lilies two Christological and Mariological meanings, essentially interrelated. We will certify now this ambivalent significance of the stem of lilies in the Annunciation's images in the light of numerous interpretations of some Church Fathers and theologians on the passage of the Song of Songs, according to which the Bridegroom (Husband) sets out in bucolic terms:

Ego sum flos campi,

Et lilium convallium. ${ }^{20}$

This lyrical floral metaphor -that in the text of the Song of Songs the Bridegroom applies to himself - is referred by the Christian writers as a symbol of Christ. In contrast, they apply to Mary the subsequent verses of the Song of Songs, delivered by the Bridegroom to exalt his beloved Wife:

Sicut lilium inter spinas

Sic amica mea inter Filias. ${ }^{21}$

Therefore, not a few Church Fathers and theologians produce from the paleochristian times numerous exegesis on "the flower of the field, and the lily of the valleys", interpreting that bucolic praise as an obvious metaphor for Christ, in his condition as God the Son incarnate in the Mary's virginal womb.

Hence, at the beginning of the third century Hippolytus of Rome (c. 170-C. 235), interpreting the biblical phrase "you have arisen, my son, my seed" as a foreshadowing of the birth of Jesus, concludes that the latter, incarnate by the grace of the Holy Spirit, germinated in the Virgin's womb, "and appeared

\footnotetext{
19 "Flos de radice Iesse. A hermeneutic approach to the theme of the lily in the Spanish Gothic painting of The Annunciation from patristic and theological sources", op. cit.; and "In virga Aaron Maria ostendebatur...", op. cit.

${ }^{20}$ Canticum Canticorum Salomoni, 2, 1. En En Biblia Sacra iuxta Vulgatam, op. cit., p. 614. ("I am the flower of the field, and the lily of the valleys.").

21 "Like a lily among thorns, so is my darling among the young women." (Ibid., 2, 2).
} 
coming into the world like a flower, and a fragrant smell." 22

Something more than a century later, St. Fortunatus of Aquileia (mid-fourth century), after stating that Aaron's rod which has flourished in the Sancta Sanctorum can be interpreted as the Lord, flower and fruit of that rod, you must see Mary, Mother of the Lord Jesus Christ, prefigured in the rod, and the same Christ prefigured in the flower, in accordance with the Isaiah's prophecy "there shall come forth a rod out of the root of Jesse". ${ }^{23}$ For this reason, the author concludes, Solomon identifies the Lord Jesus with these words: "I am the flower of the field, and the lily of the valleys". ${ }^{24}$

Some decades later St. Ambrose of Milan (330-397) argues that the work of the Holy Spirit is the birth and the fruit of the Virgin's womb, according to what is written: Blessed art thou among women and blessed is the fruit of thy womb. Or, in other words, the work of the Holy Spirit is the flower of the root, a flower prophesied in that sentence: there shall come forth a rod out of the root of Jesse and a flower shall rise up out of his root. ${ }^{25}$ In terms even more explicit, St. Ambrose goes on stating that this root is the Jewish patriarch Jesse, the rod or stem is Mary, and the Mary's flower is Christ, who spread all over the world the good smell of faith and germinated from a virginal womb, as he himself said about himself: I am the flower of the field, and the lily of the valleys. ${ }^{26}$

Some lustra later, St. Jerome (c. 347-420) refers to Jesus Christ, when, commenting on the verse of the Psalm 66 "The Earth gave its fruit," says that "first gave the flower', as it is written in the Song of Songs: I am the flower of the field, and the lily of the valleys. ${ }^{27}$ Making even more suggestive his

22 "Dixit autem ex germine, fili mi, ascendisti, ut Christi nativitatem secundum carnem mostraret; qui in sinu virginis ex Spiritu Sancto incarnatus germinavit in ipse, et sicut flos et odor fragantiae adveniens in mundum apparuit." (HIPPOLITUS ROMANUS, De benedictionibus patriarcharum 1. In Sergio Alvarez CAMPOS, Corpus Marianum Patristicum, Burgos, Aldecoa, 1970, vol. I, p. 61).

23 "Virga Aaron, quae in Sancta Sanctorum floruit, in typum Domini flos et fructus ipse virgae accipere potest. In virga quippe Mariam Genitricem Domini nostri Iesu Christi, in flore vero ipsum Dominum praefigurasse accipiendum est. Sicut Scriptura ait: « Egredietur virga de radice Iesse (Is, 11, 1) ».” (FortUnAtUS OF AQUILEA, Commentarii in Evangelia I. In AlvareZ CAMPOS 1974, vol. III: 20).

24 "Hinc de Domino Salomon ait: «Ego sum flos campi et lilia convallium (Cant. 2, 1)»." (Ibid.).

25 “Opus ergo Spiritus Virginis partus est. Opus Spiritus fructus est ventris, secundum quod scriptum est: «Benedicta tu inter mulieres et benedictus fructus ventris tui (Lc. l, 42) ». Opus Spiritus flos radicis est: ille, inquam, flos de quo bene est prophetatum: "Exiet virga de radice Iesse et flos de radice eius ascendet (Is, 1, 11) »." (ST. AMBrose, De Spiritu Sancto, Liber II, 49. PL 16,750-751).

26 "Radix Iesse patriarchae Iudaeorum, virga Maria, flos Mariae Christus, qui bonum odorem fidei toto sparsurus orbe, virginali ex utero germinavit, sicut ipse dixit: «Ego flos campi et lilium convallium (Cant. 2, 1) »." (Ibid.: 751)

27 "« Terra dedit fructum suum (Ps. 66, 5) ». Primum dedit florem. Dicit in Cantico Canticorum: « Ego flos campi et lilium convallium (Cant. 2, 1). »" (ST. Jerome, Epistula 22, 19. PL 22, 406). 
Christological interpretation, according to a clearly eucharistic projection, the erudite hermit adds that "this flower became fruit for we could savor it, for we could eat its flesh", before concluding that the fruit is "the virginal being born of a virgin, the Lord born of a slave, God incarnate in human nature, the son generated of a mother, the fruit emerged from the earth." 28

St. Jerome confirms in another passage that the stem flourished in the Jesse's root is the Lord's mother, "simple, pure, sincere, without external germ and fruitful by the work of God", while the stem's flower is Christ, to whom the Song of Songsn proclaims as the flower of the field and the lily of the valleys. ${ }^{29}$

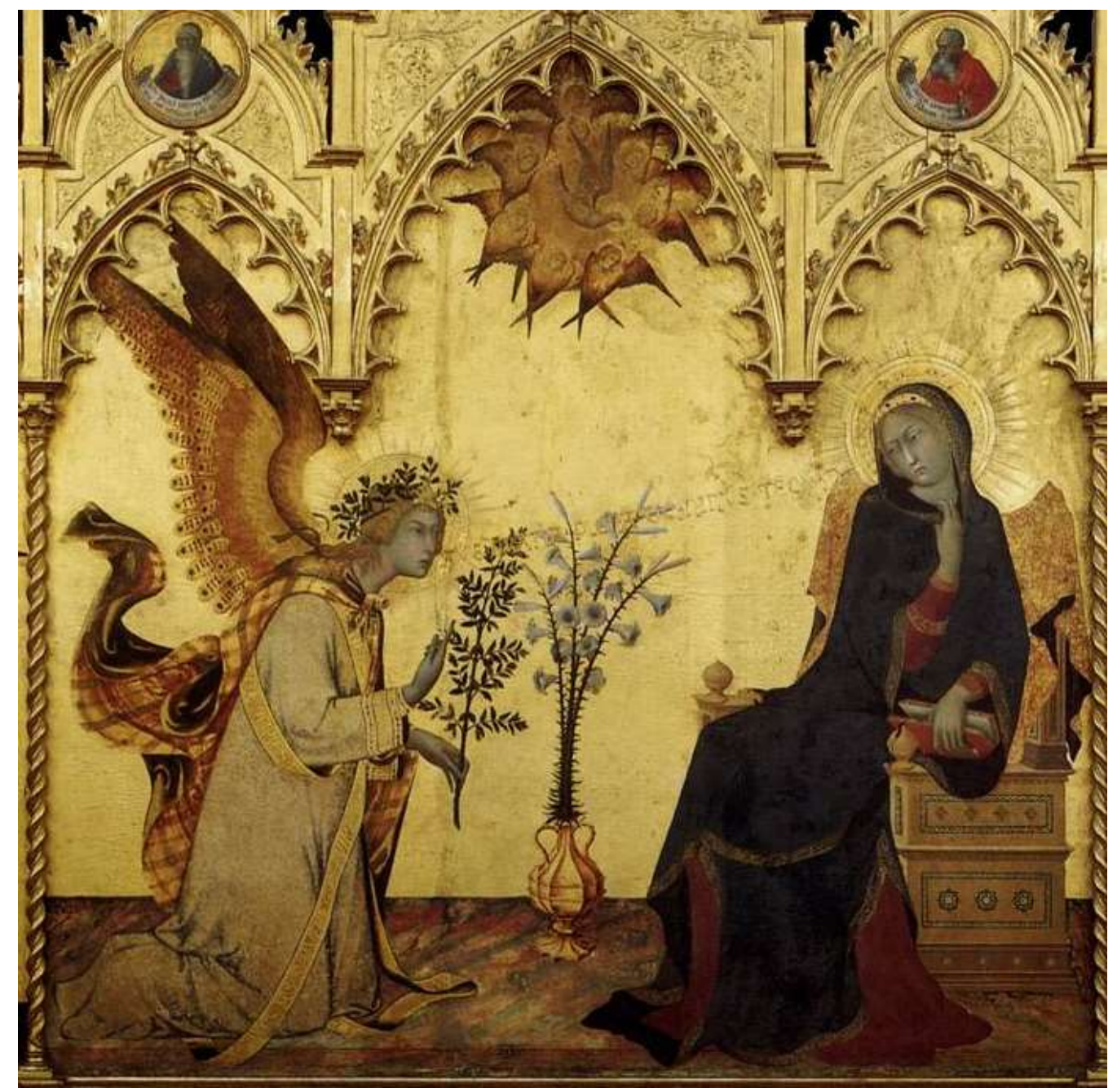

Fig. 10. Simone Martini, The Annunciation, central panel of L'Annunciazione con i Santi Ansano e Margherita, 1333. Galleria degli Uffizi, Florence. (Detail of the Fig. 3).

\footnotetext{
28 "Iste igitur flos fructus factus est, ut nos illum comederemus, ut nos manducaremus carnes ipsius. Vultis scire quid sit iste fructus? Virgo de virgine, Dominus de ancilla, Deus ex homine, filius ex matre, fructus ex terra." (Ibid.).

29 "Exiet virga de radice Jesse, et flos de radice ejus ascendet (Isai. 11, 1). Virga Mater est Domini, simplex, pura, sincera, nullo extrinsecus germine cohaerente, et ad similitudinem Dei unione fecunda. Virgae flos Christus est, dicens: Ego flos campi et lilium convallium (Cant 2, 11)." (Ibid.).
} 
More or less for the same years St. Maximus of Turin ( $\dagger$ c. 420$)$, arguing in metaphorical terms that in Christ there was no thorn of sin that would harm the flower, says that "He was the flower born not of the spine, but of the stem", in accordance with the Isaiah's fortelling on the flowering of stalk sprout from the Jesse's root. ${ }^{30}$ The saint of Turin does not doubt to emphasize that "Mary was the clear, subtle, virginal stem, who, retaining her bodily virginity, germinated Christ as a flower." 31

Toward the middle of the fifth century the monk and preacher Hesiquius of Jerusalem expresses in this order of ideas some analogies referring to the virginal mother and to her divine Son, when proclaiming:

Arise, O Lord, to your rest, you and the ark of thy holiness, the Virgin, the Mother of God evidently. Because if you [Christ] are the pearl, she is the shell; as you are the sun, the Virgin necessarily will be called heaven, as thou art flower that is not wilted, the Virgin, accordingly, is incorruptible bush, garden of immortality. ${ }^{32}$

Toward the fifth-sixth centuries an anonymous author, known as the Pseudo Augustine, after pointing out that the flower in the rod sprout from the Jesse's root ois the flesh of the Lord Jesus, who was born without the vice of the human seed ${ }^{33}$ expresses thus the double Christological and Mariological significance the engendering of the Son of God incarnate in the Mary's virginal womb - that he perceives in the metaphor of the flowering stem:

Oh royal flower! Oh flower judge! As well as the rod is not a rod (virga), but a virgin (virgo), so too this flower is not a flower of a rod, but that is flesh. Which begat certainly the flower, and begat flesh of human nature; but that bedetting did not originate in sin, for the born did not come out of manly semen, but was conceived by the Holy Spirit. $^{34}$

\footnotetext{
30 "Nec enim erat in illo spina peccati, quae verteretur in florem; ipse enim erat flos natus non de spina sed de virga, sicut ait propheta: «Exibit virga de radice Iesse et flos de radice ascendet (Isai. XI, 1) »." (ST. MAXIMUS OF TURIN, Homilia XXXIX. PL 57, 310).

31 "virga enim erat Maria, nitida, subtilis, et virgo, quae Christum velut florem integritate sui corporis germinavit.” (Ibid.).

32 Hesychius of Jerusalem, Homilia de Sancta Maria Deipara. In José María Bover, La Asunción de María. Tratado teológco y antología de textos, Madrid, La Editorial Católica, Col. BAC, 1947, p. 25 y 136.

33 "Denique quod sequitur auscultent: « Exiet virga de radice Iesse, et flos de radice eius ascendet $($ Is. 11, 1) ». Flos iste caro est Domini, quae nata sine vitio humani seminis, florentem per omnia pulchritudinem retinet societatis..." (PSEUdo AUgustine, In Natali Domini 1. In ALVAREZ CAMPOS 1981, vol. VI: 260).

34 "'O florem regem! O florem iudicem! Sicut ergo virga illa non virga, sed virgo est, sic et flos ille non flos virgae, sed caro est. Quae florem quidem peperit, et ex genere carnis carnem emisit;
} 
More or less by the same period, the conspicuous hymnograher St. Romanus the Melodist (c. 485-555/ 62) argues that the Scriptures show Jesus as the vase of the manna and as the flower sprung from the root, while his mother Mary is called flower, stem, ark, the same who gestate in her womb, opened by the Holy Spirit, and that afterwards remains closed for ever, so that all may say: "She gave birth still virgin, and after childbirth remains again virgin." 35

A couple of generations later the Italian liturgist and bishop of Poitiers St. Venantius Fortunatus (c. 530-610), in a hymn in honor of Mary, suggests the double Christological/Mariological content inextricably inscribed in the floral metaphor under analysis in this terms:

This Virgin is of whom the flower that is Christ is born,

Whose lively odor makes reemerge the members already buried. ${ }^{36}$

Half a century later, the archbishop of Toledo St. Ildefonsus (607-667) shoulders without restrictions that double dogmatic interpretation, referring to Christ as the flower of the field and the lily of the valleys, who shone as the adornment of the world when was born of the Mary's virginal sulcus, and glistened by the grace of the Virgin's humility. ${ }^{37}$

In the following century the conspicuous Syrian orator and Mariologist St. John Damascene (675-749) extols in poetic terms the Virgin, dubbing her between other metaphors "fadeless rose, infinitely fragrant [...], perfumed goblet, fruit born of a barren woman", and "lily, whose son Jesus dresses these lilies of the field, exhaling the sweet scent of the roses of the Holy Spirit". ${ }^{38}$ As if that is not enought, the fervent thinker of Damascus concludes by defining Mary as "flower $[\ldots]$ from which another flower similar to her arose, in perfect and accurate reference to his mother". ${ }^{39}$

sed originem peccati illa generatio non habuit, quia non ex viri semine natus extitit, sed de Spiritu Sancto conceptus exivit." (Ibid.).

35 "Te, Iesu, monstrat Scripturas: alia manna et vas indicat, alia vero ex radice florem nuntiat. Et matrem tuam vocant florem, virgam, arcam, eam quae sinu portat per Spiritum aperta et post haec manet clausa; ut quisquis dicat: Virgo parit, et post partum iterum manet virgo." (ST. Romanus the Melodist, Hymnus 12, 6. In Alvarez CAMPOS 1979, vol. IV/2: 129-130).

36 "Virgo haec virgo fuit de qua est flos Christus obortus, / cuius odor vivax membra sepulta levat." (St. VENANTIUS FORTUNATUS, Caput VII. In laudem sanctae Mariae Virginis et matris Domini. PL 88, 277).

37 "Ibi flos campi et lilium convallium, quia idem Christus de surculo virginalis corporis exortus mundi decus enituit, et humilitatis virginum gratia praefulsit." (ST. ILDEFONSUS OF TOLEDO, De itinere deserti, 30. In AlVAREZ CAMPOS 1981, vol. VI: 474).

38 "Ave, rosa immarcessibilis, infinite fragrans [...]. Ave, pomum bene olens, fructus sterile prognatus, ac divina venustate decorus [...]. Ave, lilium, cujus proles Jesus haec agri lilia vestit; suave spirans Spiritus rosarium". (ST. JoHn Damascene, Homilia II In Nativitatem B.V. Mariae, 7. PG 96, 691).

39 "Ave, flos, prae cunctis tinctorum coloribus varium omni virtute condimentum, ex qua flos flore similis, matrem exacte referens consurgit". (Ibid.). 
Already in the eleventh century, the Benedictine cardinal and theologian St. Peter Damian (1007-1072) says that Christ is the unique flower of the holy Church, in accordance with what is said in the Song of Songs "I am the flower of the field, and the lily of the valleys" ${ }^{40}$ With a clear catechetical purpose, the holy Doctor adds that this lily which is Christ is not born in the mountains, but in the valleys, since God, who resists the proud, dwells in the hearts of the humble. ${ }^{41}$

In the subsequent century the influential Cistercian reformer St. Bernard (1090-1153), abbot of the monastery of Clairvaux, known as Doctor Mellifluus, is the Christian intellectual that more assiduously interprets this metaphor of the flower and the lily as identifier of Jesus. So that, in a first sermon for the Advent season, after enouncing that the Holy Spirit perched on the flower sprung in the stalk sprout from the Jesse's root, on the basis of the Isaiah's prophecy, ${ }^{42}$ says:

That has been expressed more clearly by the prophet himself in another passage: the virgin shall conceive and bear a son, and shall call his name Emmanuel, which means God with us. He first calls him Flower, and afterwards Emmanuel. And whom he had called rod, calls more clearly virgin. ${ }^{43}$

And in his second homily for the same feast, the abbot of Clairvaux asserts that the stem flourished in the Jesse's root is the Virgin Mary, and his Son Jesus is the flower, ${ }^{44}$ of whom says that he is a "white and rosy flower, chosen among thousands of them, a flower at which the angels desire to look, a flower whose fragrance revives the dead", a flower of such a nature that "as he himself testifies,

\footnotetext{
40 "Singularis namque flos sanctae Ecclesiae ipse est, sicut de semetipso in Canticis canticorum loquitur, dicens: "Ego flos campi, et lilium convallium (Cant. II). »" (ST, PETER DAMIAN, Sermo XLVI. III. In Nativitate Beatissimae Virginis Mariae (VIII Sept.). PL 144, 754).

41 "Hoc lilium non in montibus, sed in convallibus nascitur, quia superbis Deus resistens, in humilium cordibus invenitur. Lilium vocatur Christus, lilium dicitur et mater Christi, sicut in eodem Cantico subinfertur: "Sicut lilium inter spinas, sic amica mea inter filias (Ibid.). "” (Ibid.).

42 "Ex his montibus prodiit, ut invenies, radix Iesse, unde, iuxta Prophetam, egressa est virga, et exinde flos ascendit, super quem requievit Spiritus septiformis." (ST. BERNARD, In Adventu Domini. Sermo Primus, 11. In Obras completas de San Bernardo. Edición bilingüe promovida por la Conferencia Regional Española de Abades Cistercienses, vol. III. Sermones litúrgicos $\left(1^{\circ}\right)$, Madrid, La Editorial Católica, Col. BAC, 1985, p. 68).

43 "Quod manifestius alio in loco aperiens ídem Proheta: Ecce, inquit, virgo concipiet et pariet filium, et vocabitur nomen eius Emmanuel, quod interpretatur Nobiscum Deus. Quem enim prius florem, ipsum deinde Emmanuelem nominavit, et quam dixerat virgam, manifestius exprimens, virginem nominavit." (Ibid.).

44 "Ex his iam manifestum arbitror, quænam sit virga de radice Iesse procedens, quis vero flos super quem requiescit Spiritus Sanctus. Quoniam Virgo Dei genitrix virga est, flos Filius eius." (ST. Bernard, In Adventu Domini. Sermo Secundus. In Obras completas de San Bernardo. Edición bilingüe promovida por la Conferencia Regional Española de Abades Cistercienses, vol. III. Sermones litúrgicos $\left(1^{\circ}\right)$, op. cit., 1985, p. 74).
} 
is the flower of the field, not of a garden." 45

St. Bernard sees in this last sentence a neat metaphor for the Mary's virginal divine motherhood. In his opinion, in effect, as well as "The field flourishes without human intervention", because "Nobody plants it, nobody digs it, nobody fertilizes it", in the same way "the Virgin's womb flourished" without external manly intervention. ${ }^{46}$

And, in several passages of his sermon 47 on The Song of Songs, St. Bernard refers to Jesus Christ as the flower of the field and the lily of the valleys. Jus like that, after pointing out in a first exegesis on the biblical verse that "the Husband clarifies that he is the flower of the field, and that the flowers do not can sprout in the thalamus, but in the field", sets out in rhetorical circumlocution:

The garden is maintained flowery with the work and the art of man; the field produces the flowers naturally, by itself, without the help of the human skill. Have you guessed what is this field not open by the ploughshare, or removed with the hoe, or enriched with manure, or planted by man, but embellished by this noble flower upon which the spirit of the Lord descended? ${ }^{47}$

Shortly after the author settles that "It was inappropriate that he who is the flower always fresh, would call himself flower of a nuptial chamber, nor of a flower of garden, since everyone would consider that he would have been born thanks to the human effort". 48 A little later St. Bernard establishes his conclusive position on the particular in these terms: "That is why [Christ] says with all property and beauty, I am the flower of the field, which sprang without human industry, because once born was not overpowered by the corruption". 49

And, in another paragraph of that same sermon, the Doctor Mellifluus adds

\footnotetext{
45 "Flos utique Virginis Filius, flos candidus et rubicundus, electus ex millibus, flos in quem prospicere desiderant angeli, flos ad cuius odorem reviviscum mortui, et, sicut ipse testatur, flos campi est, et non horti. Campus enim sine omni humano floret adminiculo, non seminatus ab aliquo, non defossus sarculo, non impinguatus fimo. Sic omnino, sic Virginis alvus floruit, sic inviolata, integra et casta Mariae viscera, tamquam pascuae aeterni viroris florem protulere, cuius pulchritudo non videat corruptionem, cuius gloria in perpetuum non marcescat." (Ibid.).

46 "Campus enim sine omni humano floret adminiculo, non seminatus ab aliquo, non defossus sarculo, non impinguatus fimo. Sic omnino, sic Virginis alvus floruit, sic inviolata, integra et casta Mariæ viscera, tamquam pascuæ æterni viroris florem protulere, cuius pulchritudo non videat corruptionem, cuius gloria in perpetuum non marcescat." (Ibid.).

47 "hortus quidem, ut floreat, hominum manu excolitur et arte campus vero ex semetipso naturaliter produci flores, et absque omni humanae diligentiae adiutorio. Putasne iam tibi videris advertere quisnam ille sit campus, nec sulcatus vomere, nec defossus sarculo, nec fimo impinguatus, nec manu hominis seminatus, honestatus tamen nihilominus nobili illo flore, super quem constat requievisse Spiritum Domini? " (Ibid: 618).

48 "Non se proinde debuit florem thalami protestari qui flos est perpetuo vigens, sed neque ítem horti, ne humano videretur opere generatus." (Ibid.)

49 "Pulchre autem et convenientissime flos campi sum, ait, qui et absque humana industria prodiit, et semel prodeunti nulla est deinceps dominata corruptio". (Ibid.).
} 
new exegetical implications to the double Christological/Mariological metaphor of the flower and stem, by preaching that Jesus is "the flower of the garden, begotten virgin of the virgin offshoot. He is the flower of the field, the martyr, the crown and the exemplar of the martyrs." 50

And if that was not enough, in his third homily on the Annunciation, St. Bernard, based on the premise that Christ, the flower on the outbreak of the root of Jesse, loves the homeland of the flowers, infers that, being "the flower of the field, and the lily of the valleys", he is pleased to "feed between the lilies".

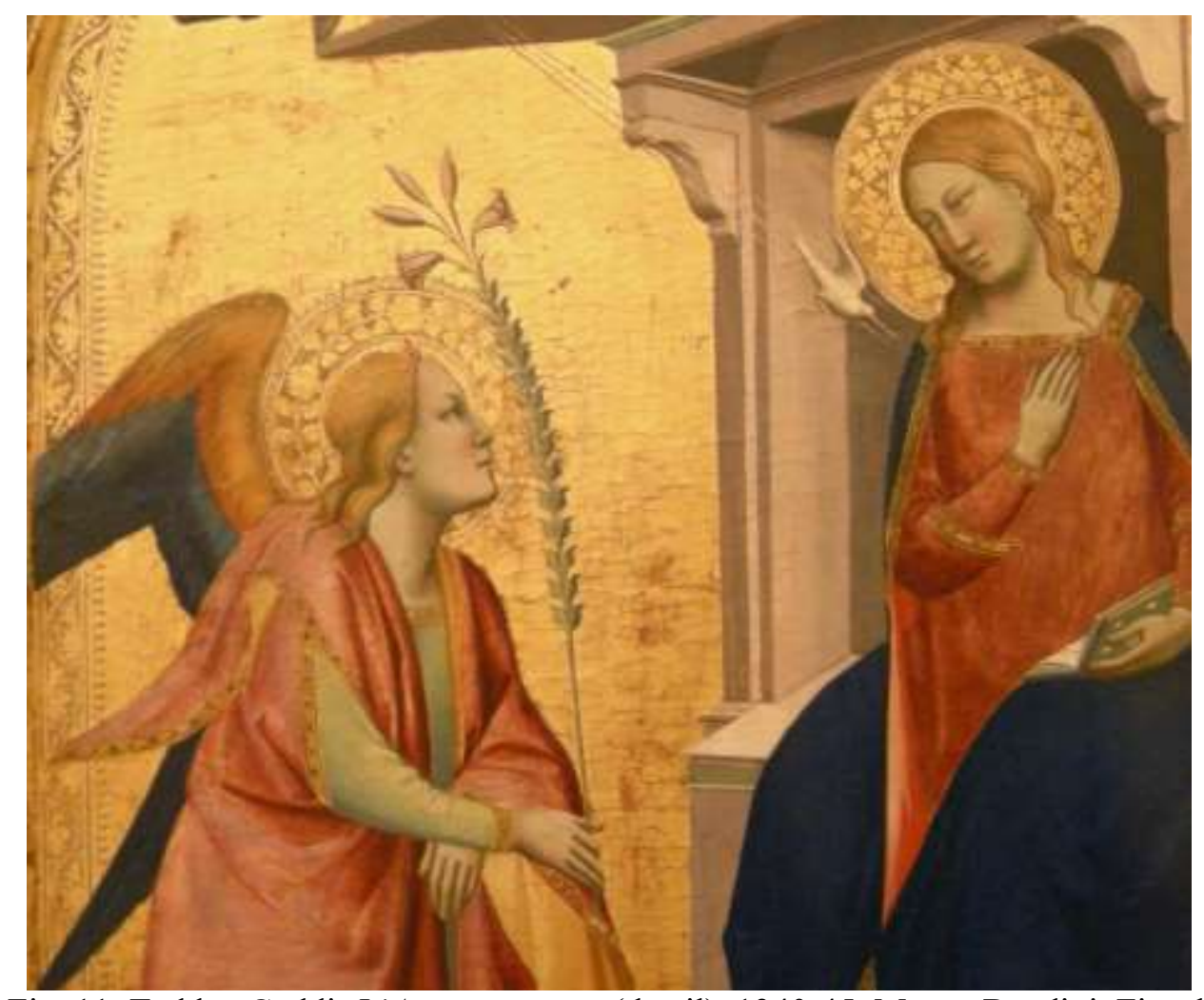

Fig. 11. Taddeo Gaddi, L’Annunciazione (detail), 1340-45. Museo Bandini, Fiesole.

(Detail of the Fig. 5)

In the following century the Franciscan mystic St. Bonaventure (1218-1274), known as Doctor Seraphicus, exposes that, if all the saints are fruits of God, Jesus Christ is more rightly so, he who, begotten by God and conceived by the Virgin Mary through the Holy Spirit, sprang from human nature as a rose among thorns, in accordance with the Isaiah's prophecy about the flower that would emerge from the shoot sprung up in the Jesse's root. ${ }^{52}$

50 "Et haec omnia, secundum aliquid, Doiminus Iesus, Ipse flos horti, virgo virga virgine generatus. Idem flos campi, martyr, martyrum corona, martyrii forma." (Ibid.: 620).

51 "Amat florigeram patriam flos de radice Jesse, et libenter inter lilia pascitur flos campi et lilium convallium." (ST. BerNARD, De Annuntiatione Beatae Mariae. Sermo III. PL 183, 396. In Obras completas de San Bernardo. Edición bilingüe, op. cit., Vol. III. Sermones Litúrgicos $\left(1^{\circ}\right), 1985$, p. 684).

52 "Fructus divini sunt omnes sancti et iusti, sed specialiter ipse Iesus Christus, qui est a Deo Patre genitus et a Virgine María conceptus per Spiritum sanctum, qui ex humana natura 
And in his fifth sermon on the Assumption, noting that "The whiteness of the continence communicated to the Virgin is designated in the whiteness of the flower", the Seraphic Doctor refers to what the Husband says of the Wife in the Song of Songs, when exclaiming: "I am the flower of the field, and the lily of the valleys. Like a lily among thorns, so is my darling among the young women." 53

\section{Conclusions}

We could synthesize thus the essential results of our analysis of the artistic works and the doctrinal quotations studied here:

The stem of lilies constitutes -as the nine Italian Trecento paintings newly analyzed reveal - a frequent iconographic detail, with a clear role in the late medieval representations of The Annunciation.

The outstanding prominence of the stem of lilies in this Marian scene can only be explained through its direct symbolic relationship with the conceptual content of the depicted event.

An extensive tour of the writings of the Church Fathers and the medieval theologians allows us to discover a solid and consistent exegetic tradition on the verse of the Song of Songs "I am the flower of the field, and the lily of the valleys".

Such a tradition gives us the key to understanding the iconographic detail under scrutiny, since it is extremely eloquent to note that all the ecclesiastical commentators on this biblical verse match in considering it as a direct reference to Jesus Christ.

The exegesis of these doctrinal authors converge unanimously in one direction simultaneously Christological and Mariological, by identifying this sentence from the Bible as a metaphor which identifies Christ, the Son of God made man, and as rebound also Mary, in whose virginal womb occurs the God the Son's incarnation.

In light of this consistent patristic and theological tradition on the aforementioned verse of the Song of Songs, it looks reasonable to interpret the stems of lilies in the pictures of The Annunciation as a double metaphor, which means at the same time the supernatural human incarnation of God the Son and the virginal divine motherhood of Mary.

$$
* * *
$$

pullulavit sicut rosa de spina, quae inter flores ratione pulchritudinis obtinet principatum; Isaias undécimo: Egredietur virga de radice Iesse, et flos de radice eius ascendet." (ST. Bonaventure, De Annuntiatione B. Virginis Mariae. Sermo II. In Obras de San. Buenaventura. Edición bilingüe. Vol. IV. Teología mística, Madrid, La Editorial Católica, Col. BAC, 1953, p. 621-622).

53 "Candor continentiae Virginis designatur in candore floris; unde de ipsa merito dicit Sponsus Canticorum secundo: Ego flos campi et lilium convallium. Sicut lilium inter spinas, sic amica mea inter filias." (ST. BONAVENTURE, De Assumptione B. Virginis Mariae. Sermo V. In Obras de San. Buenaventura, op. cit., Vol. IV, 1963, p. 726). 
José María SAlVAdOR GonZÁlez, Flos campi et lilium convallium. Third interpretation of the lily in the iconography of The Annunciation in Italian Trecento art from patristic and theological sources

\section{Sources and Bibliography}

\section{Sources}

Alvarez Campos, Sergio, Corpus Marianum Patristicum, Burgos, Aldecoa, 1970-1981, 7 vols.

Biblia Sacra iuxta Vulgatam Clementinam. Nova editio (Logicis partitionibus aliisque subsidiis ornata a Alberto Colunga et Laurentio Turrado), Madrid, La Editorial Católica, Biblioteca de Autores Cristianos, 12a edición, 2005, p. 1011.

Canticum Canticorum Salomoni, 2, 1. In Biblia Sacra iuxta Vulgatam, op. cit., p. 614.

HipPOLITUS Romanus, De benedictionibus patriarcharum 1. In Sergio ALVAREZ CAMPOS, Corpus Marianum Patristicum, Burgos, Aldecoa, 1970, vol. I, p. 61).

Pseudo Augustine, In Natali Domini 1. In Alvarez Campos 1981, vol. VI: 260.

St. Ambrose, De Spiritu Sancto, Liber II, 49. PL 16, 750-751.

St. Bernard, In Adventu Domini. Sermo Primus, 11. In Obras completas de San Bernardo. Edición bilingüe promovida por la Conferencia Regional Española de Abades Cistercienses, vol. III. Sermones litúrgicos $\left(1^{\circ}\right)$, Madrid, La Editorial Católica, Col. BAC, 1985, p. 68).

St. Bernard, In Adventu Domini. Sermo Secundus. In Obras completas de San Bernardo. Edición bilingüe promovida por la Conferencia Regional Española de Abades Cistercienses, vol. III. Sermones litúrgicos (1 ${ }^{\circ}$ ), op. cit., 1985, p. 74).

St. Bernard, Sermones sobre el Cantar de los Cantares, Sermo XLVII, I, 3. In Obras completas de San Bernardo. Edición bilingüe, op. cit., Vol. V. Sermones sobre el Cantar de los Cantares, 1984, p. 616).

St. Bernard, De Annuntiatione Beatae Mariae. Sermo III. PL 183, 396. In Obras completas de San Bernardo. Edición bilingüe, op. cit., Vol. III. Sermones Litúrgicos (1 $\left.{ }^{\circ}\right), 1985$, p. 684).

St. Bonaventure, De Annuntiatione B. Virginis Mariae. Sermo II. In Obras de San. Buenaventura. Edición bilingüe. Vol. IV. Teología mística, Madrid, La Editorial Católica, Col. BAC, 1953, p. 621-622.

St. Bonaventure, De Assumptione B. Virginis Mariae. Sermo V. In Obras de San Buenaventura, op. cit.,

St. Fortunatus of AQuileA, Commentarii in Evangelia I. In Alvarez CAMPOS 1974, vol. III: 20.

St. Ildefonsus of Toledo, De itinere deserti, 30. In Alvarez CAMPOS 1981, vol. VI: 474.

ST. JEROME, Epistula 22, 19. PL 22, 406.

St. John Damascene, Homilia II In Nativitatem B.V. Mariae, 7. PG 96, 691.

St. MÁXIMUS OF TURIN, Homilia XXXIX. PL 57, 310.

St. Peter Damián, Sermo XLVI. III. In Nativitate Beatissimae Virginis Mariae (VIII Sept.). PL 144, 754. 
St. Romanus the Melodist, Hymnus 12, 6. In Alvarez Campos 1979, vol. IV/2: 129-130).

Venantius FortunAtUs, Caput VII. In laudem sanctae Mariae Virginis et matris Domini. PL 88, 276-284.

VorÁGINE, Santiago de la, La Leyenda Dorada (Traducción del latín: Fray José Manuel Macías), Madrid, Alianza Editorial, Col. Alianza Forma, 29-30, 1990, 2 vols.

\section{Bibliography}

Bover, José María, La Asunción de María. Tratado teológico y antología de textos, Madrid, La Editorial Católica, Col. BAC, 1947, p. 25 y 136.

SAlVADOR GONZÁLEZ, José María, "Flos de radice Iesse. A hermeneutic approach to the theme of the lily in the Spanish Gothic painting of The Annunciation from patristic and theological sources", Eikón Imago, 4, JulyDecember 2013, Madrid, Universidad Complutense de Madrid, p. 183-222.

SALVADOR GONZÁLEZ, José María, "In virga Aaron Maria ostendebatur. Nueva interpretación del ramo de lirios en La Anunciación gótica española a la luz de fuentes patrísticas y teológicas", Anales de Historia de Arte, $\mathrm{n}^{\mathrm{0}}$ 24, Universidad Complutense de Madrid, 2014, p. 37-60 